\title{
Private Enterprise in a Prison
}

\section{The Free Market Economy of La Mesa Penitenciaria}

\author{
John A. Price \\ Associate Professor, Department of Sociology and Anthropology, \\ York University (Downsview, Ont., Can.) \\ Assistant Professor, University of California (Los Angeles), 1965-67; \\ Assistant Professor, San Diego State College, 1967-70 \\ B.A., 1959, M.A., 1962, University of Utah; Ph.D. (Anthropology), 1967, \\ University of Michigan
}

As illustrated by La Mesa Penitenciaria, near Tijuana in the state of Baja California, the strongest and most pervasive feature of life in the Mexican prison is not the formal administration but the prison's private enterprise economy.

Conjugal visits by the prisoner's spouse, as well as long and very open family visits, are regularly permitted. In these contacts quantities of food, clothing, and money are allowed to be given to the prisoners. A market system then develops out of the barter of these goods, the purchase of bedding and special sleeping quarters, and the operation of stores, restaurants, and small manufacturing firms. The resulting prison society is thus similar to the social realities outside the prison, and it draws the inmates into daily economic decisions.

On busy visiting days the large open prison yard takes on the atmosphere of a bustling Mexican village. The prisoners do not wear uniforms, so they do not stand out. They have their large family groups around them, perhaps sharing some food and talking or singing along with a guitar. Children chase one another across the yard. A jukebox blares from one of the privately run restaurants. Craftsmen and ice cream vendors come around trying to peddle their wares. While La Mesa Penitenciaria has very serious problems, such as its heroin trade, for most of its inmates it is a humane prison.

$\mathbf{T}$ he Mexican Penal system officially allows much greater interaction. between inmates and their outside friends and relatives than is generally allowed in the United States, Canada, and Europe. For example, long and private visits by the prisoner's spouse or whole family are regularly permitted throughout Mexico. Children born to female inmates may be raised for years in the prison. Large quantities of food, clothing, and other goods are carried in to the prisoners by relatives.

Rather than generate a highly disciplined program for the prisoners, the officials allow a fairly self-disciplining prison subculture to form, largely along lines that parallel the culture of the lower social class of the wider 
society. The extensive interaction with the outside and the permissiveness inside promote the development of an elaborate free enterprise system in the prison. Within this economic system, a prisoner's wealth, industriousness, and bartering ability determine the nature of his food, living quarters, dress, and social status.

La Mesa Penitenciaria, the major prison of the Mexican state of Baja California, is particularly useful as a study in adaptation because it has a large number of American prisoners. Americans usually undergo great cultural shock when they are incarcerated in a Mexican prison. In addition to the stress of confinement, they generally cannot speak Spanish, they do not understand Mexican customs, and they abhor what are essentially lowerclass Mexican food, housing, and standards of medicine and cleanliness. However, they form alliances with other Americans and, because of their greater wealth, are usually among the prison's elite.

The data for this account of the economy of La Mesa Penitenciaria were collected primarily by observing and interviewing in the prison from 1968 to 1970 through regular visits to inmates. ${ }^{1}$

1. For background materials on Tijuana see John A. Price, "Tijuana: a Study of Symbiosis," New Mexico Quarterly, 38, No. 3, 1968, pp. 8.18; and "International Border Screens and Smuggling," Occasional Papers, Border-State University Consortium for Latin America, University of Texas at El Paso, No. 2, 1971, pp. 22-42. Ethnographic details on the prison are in Bernadine $B$. Boysen, "La Mesa Penetario: An Ethnography of Baja California's State Prison," M.A. thesis, San Diego State College, 1970. Although sensational and anti-Mexican in approach, the following does contain some useful data on the present subject: Ovid Demaris, Poso del Mundo: Inside the Mexican-American Border from Tijuana to Matamoros (Boston and

\section{Tijuana-Its Crime and Its Criminals}

La Mesa, the location of the prison, is a delegacion (township) in the eastern suburbs of the municipio (county) of Tijuana.

Many Americans know of Tijuana's reputation as a historic center of vice with gambling casinos, houses of prostitution, pornographic literature, and rough bars. However, the gambling casinos and sales of pornographic literature were eliminated years ago. Prostitution has been suppressed until it is only a minor trade that operates on the fringes of the tourist traffic. Tijuana receives over eleven million American tourists a year, mostly in family groups, who buy souvenirs and go to the horse races, the bull fights, or the jai alai games. According to the 1970 census, it has a population of 385,000 ; hundreds of industrial companies that manufacture such items as radios, television receivers, clothing, furniture, and cigarettes; and, compared to the rest of Mexico, the very high per capita income of $\$ 1,045$. In brief, outside of its tourists and its affluence, Tijuana today is a fairly normal, industrious, large, and peaceful Mexican city.

Only about 0.1 per cent of the Americans who come to the TijuanaEnsenada area are arrested, mainly for traffic violations or misdemeanors such as being drunk and disorderly, disrespect for police officials, and urinating in a public place. The standard penalty for these misdemeanors is a \$24 fine. When the annual tourist traffic is eleven million, even onetenth of 1 per cent comes to the large figure of 11,000 persons, and an aver-

Toronto: Little, Brown, 1970). The nature of the prison social structure led Demaris into interviewing some of the same prisoners that Mrs. Boysen and I interviewed. 
age of about 5,500 Americans are actually held each year. Finally, roughly twenty-five Americans are accused of felonies and are sent to La Mesa Penitenciaria each year to wait a few months until their trials come up and to serve out their sentences if they are convicted. Most felonies are not bailable in Mexico.

The most frequently committed felony by Americans in Baja California is possession of or the attempt to purchase marijuana or other illegal drugs; it carries a minimum sentence of three years of imprisonment. Then, in order of frequency with their mini. mum sentences in months, Americans are committed to La Mesa Penitenciaria for fraud or attempting to pass counterfeit U.S. currency (over 3,000 pesos-three years), grand theft (over 500 pesos-two years), and other crimes (assault - one year; abortionthree months to one year; rape-six months; and murder-two to twenty years). The most common felony of the Mexicans is grand theft, especially armed robbery, but much of it is committed by heroin addicts and is in fact a drug-related crime.

When our study began in the summer of 1968 the prison had the following estimated composition of 800 inmates: 725 Mexicans; 40 Americans; and 35 Cubans, Filipinos, and other Spanish-speaking prisoners. Twentyfive of the Mexicans and one American were female. The age range of the prisoners was from eighteen to seventy, with the average in the thirties.

\section{Description of the Prison}

La Mesa was built in 1961. The outside is a double concrete block wall with a walkway along the top. In area it is somewhat larger than a city block, about 350 feet on each side. The walls are about fifteen feet high, with wooden watch towers at the corners and at the center of each wall. The prison buildings inside are close to this wall, leaving a large open court in the center. The only entrance is through a heavy gauge chain-link gate, which leads to a small reception yard where visitors register. To the right of the reception yard are rooms where visitors are inspected for weapons, narcotics, and alcoholic beverages; after inspeotion, they continue on through a second chain-link gate to the central courtyard.

Around the wall, in a clockwise direction from the entrance, the main prison buildings-a mix of clapboard, stucco, and concrete constructionare offices, four large commercial workshops, an apartment complex, other shops, another apartment building, the main "corral" with its four sleeping quarters or "tanks," a kitchen, a bakery, the solitary confinement cells, a restaurant, a tortilla shop, more apartments, a barber shop, a market, the infirmary, the selfcontained women's quarters, and a shoeshine stand. Looking across the large central dirt plaza, one rarely sees more than two hundred prisoners in scattered groups; most men stay in the workshops or their quarters.

\section{STAFF}

The warden is politically appointed for a six-year term. The appointment is considered to be important because, in addition to his salary from the very low operating budget, the warden also draws off money from the internal prison economy. His role seems to be simply to keep the prisoners contained, alive, and at peace with one another.

Under the warden are four commandants, one of whom is always on duty at the prison. Under the com- 
mandants are fifty guards, two matrons, and several clerical workers. The rest of the work in the prison is done by the prisoners.

The guards are officially paid $\$ 3.30$ per day and work shifts of twenty-four hours on and twenty-four hours off. They dress in a uniform style common among Mexican police-beige trousers and tan shirts-and often carry rifles or pistols in the prison, especially at night, but there is very little friction between guards and prisoners. One reason for this amiability is that the guards are culturally close to the prisoners; another is that, selected for physical prowess, they tend to be larger and stronger than the prisoners. Some of the guards were previously prisoners themselves at La Mesa Penitenciaria. Several prisoners once playfully took the pistol away from a guard in the courtyard and teased him with it for several minutes before returning it. They were not punished.

The guards have well-defined social and economic roles within the prison. They collect the talacha (the weekly upkeep-and-repair donation) ${ }^{2}$ and money from prisoners purchasing blankets, beds, apartments, and the use of shower facilities - the common mordidas (literally, "little bites") that prisoners pay. The guards can also procure illegal goods, such as narcotics, and illegal services, such as female inmates as prostitutes, for prisoners with the money to pay for them. In fact, the relationship between the guards and the prisoners is so familiar that, under the warden's clearly stated policy, any guard who allows a prisoner to escape must serve out the rest of the escapee's sentence.

2. This averages about $\$ 2$ a week for everyone who does not have a regular job in maintenance, the kitchen, or the infirmary.
The infirmary is staffed by prisoners. Its current head is a man serving a sentence for having performed abortions. Medical care is free from 6:00 to 7:00 A.M. and from 3:00 to 4:00 P.M., but it is crowded at these times. The most prominent chronic medical problems among the prisoners are, in order of importance, drug addiction, venereal disease, tuberculosis, and hepatitis. One of the women gave birth in the prison infirmary about a year ago; she has been allowed to keep and raise the child in the prison.

\section{Living Quarters}

The prisoner registers at admission. There is no physical examination. He is not issued a uniform; he simply wears the clothes he had when he came in.

After registration he is required to buy his living accommodations, including blankets, a bed, and sleeping quarters.

Although prices vary somewhat according to the prisoner's ability to pay, the usual fees in one of the dormitory tanks are a few dollars for a bedroll on the floor, $\$ 35$ for a cot, and $\$ 100$ for a choice bunkbed.

For more money a prisoner may stay in a caraca, an individual apartment, which costs from $\$ 200$ for a makeshift clapboard room to $\$ 500$ for a room in a new concrete block. In 1968 one well-to-do Mexican had a second-floor caraca with a stairway to his own patio furnished with a sunshade, several chairs, a barbecue brazier, and potted plants. A recent count listed fifty-five caracas, but there is a continuous building program to accommodate wealthy newcomers. ${ }^{3}$

3. In adclition to the regular talacha (sec upra, note 2), a caraca inmate pays 54 to use the toilet and $25 \%$ to take a shower (fiftectiminute limit for both), or a flat $\$ 1.50$ a week for use of the toilet and shower facilities. 
A caraca has a door, of course, and a window and usually measures $7^{\prime} \mathbf{x}$ $9^{\prime}$. It may be furnished any way that the prisoner can afford and the small space permits. Most caracas have at least a bunk bed (single or double), a hot plate, and a radio; some have such things as a television receiver, books, a musical instrument, and a refrigerator. Several of the caraca dwellers keep dogs as pets; many pay other prisoners to be their servants. The servant runs errands, fixes meals, and cleans the tiny apartment.

If the prisoner has no money at all he simply sleeps in his clothes on the floor of a tank.

Regardless of their affluence, prisoners who are security risks are contained in the solitary confinement cells or in the Corral, four two-story tanks surrounded by a high chain-link fence.

Outside of the Corral is a new twostory tank arranged so that each floor is a long corridor of double bunk beds. This structure was built by a Mexican contractor while he was a prisoner.

Tiny makeshift apartments have recently been constructed out of plywood and cardboard in two tanks.

The poorer tanks have no place for the storage of personal belongings, so these are kept in the prisoner's bedroll. The old tanks have dirt floors and are crowded and poorly lighted. There is so much cardboard and light wood in the construction and so much loose junk in these areas that fires frequently sweep through a tank. Tank conditions are so chaotic that two Mexicans and an American were able to escape by digging a twentyfoot tunnel, over a period of several weeks, from their tank to outside the wall. There have been a few other escapes over the wall.

\section{FooD}

There are several possible arrangements for food. Standard prison fare is prepared by a group of prisoners in the kitchen and is served free to the 685 state prisoners. The typical daily menu of the prison kitchen is a roll, coffee, and oatmeal for breakfast; a roll and soup for lunch; and a roll, coffee, and beans for supper. (Anyone with money supplements this with food from other sources.) At mealtime each prisoner brings a bowl that he has fashioned from a tin can or a plastic container, into which the food is ladled. There is no dining room; the men simply squat on the ground or lean against a wall to eat.

The fifteen prisoners convicted of federal crimes are given $31 / 2$ pesos a day $(28 \phi)$ to buy the standard prison fare or to buy food from other sources in the prison: six grocery stores, two restaurants, a tortilla shop, and, until the fall of 1969, four carretones (small hand carts), each of which specialized in one food: tacos, soft drinks, ices and ice cream, and fruit. This special arrangement for the federal prisoners was established to avoid the local mismanagement of food money.

The small markets sell canned and packaged goods and are patronized by those who prepare their own food. One restaurant serves a full menu of sandwiches, tacos, enchiladas, tamales, steaks, bakery goods, and soft drinks.

Friends and relatives of a prisoner bring him sacks of food, which he may use for his own meals and also as "valuta" in the prison barter system. The exchange discussion may take only a few minutes or may stretch out to several days; acquiring a new mattress or a refrigerator or a television set may involve weeks of negotiations 
and mordida payments. The men have plenty of time and many of them enjoy the competitive gamesmanship of bartering. The prisoner who acquires goods and services through skillful bartering is admired. Addicts are despised when they sell off for a pittance the bags of groceries their relatives bring them.

The most commonly stolen item is food, not for personal consumption but for its value in bartering for some other desired item, such as drugs, a knife, a blanket, or a shirt.

\section{WORK}

Prisoners may earn $\$ 1.50$ a day in the commercial workshops. Several private companies lease space within the prison, supply the necessary mate. rials, and pay the prison a fixed amount for each item produced. These workshops produce such things as carved wooden furniture, bed frames, tambourines, bongo drums, and miniature carved wooden ships. A "service fee" is taken out of the worker's paychecks; that is, the prison officials collect mordidas on the workshop industries from both the companies and the workers. No one is required to work and no American does; however, if a prisoner's visitors do not bring him any money or food for barter, the economic demands of the prison may force him to take gainful employment in a shop, as a servant, or in the drug trade.

\section{Drugs}

One of the most pervasive economic demands within the prison is for drugs of all kinds, especially heroin. In the summer of 1968 , prisoner informants' estimates of the number of heroin addicts in the prison with a need for a daily "fix" ranged from a hundred to two hundred Mexicans and sixteen Americans. The number of Mexican addicts significantly increased in the next two years; by August 1970 the estimates ranged from two hundred to three hundred Mexicans and fifteen Americans. Though the total prison population also increased in these two years, it now appears that roughly one-fourth of the Mexicans are taking heroin. The cost of a "paper," a small packet of diluted heroin, is $\$ 1$. The "shooting gallery" I visited was located in a burned-out caraca.

All of the dealers in 1970 were Mexicans. There was one major dealer on the north side of the prison and another one on the south side. Each had a gang of several convict guards and "runners," and each gang tended to stay in its own territory. In the spring and summer of 1970 the northern gang was reduced from ten to three when some members defected to the south and others quit the trade out of fear. One man was blinded when he was shot three times in the head with a small caliber pistol.

Each of the two major dealers sells about one hundred "papers" a day. There are also several other smaller dealers.

\section{Prison Life Styles}

The roll call (lista) is held twice a day, at 7:30 A.M. and 7:30 P.M., in domicile groups. There is a general cleanup period after each meal. The doors to the tanks are locked at night between the evening and morning roll calls; caraca dwellers are not allowed out at night, except to go to the lavatory with the permission of the guards. Other than these formalities, the prisoners are on their own to work, lounge, or play. Some prisoners spend hours gossiping, gambling for petty stakes with dominoes or cards, 
or just strolling back and forth across the prison grounds. The Americans get particularly lethargic and depressed, often "tuning out" the ugliness and noise of the prison by reading or watching television. Some of the prisoners have organized themselves into baseball and soccer leagues that play a schedule of games in the central court. The baseball team, Tigres de la Mesa, plays teams from outside the prison.

The prison routine is broken somewhat by visiting days, the visit by a Catholic priest once a week, and occasional small feasts. A Protestant missionary couple comes in once a week, and there is a small church, Iglesia de Dios en Christo, in the Corral. At times on busy visiting days you feel you are in a bustling Mexican village or on a side street in Tijuana: children are running and shouting; a jukebox blares from a restaurant; people are playing guitars or have their radios turned on. You see large family groups and, since the prisoners do not wear uniforms, they do not stand out. One group has purchased a live pig, has slaughtered it, and is cooking it in the prison yard. A goat and a cow are left to forage between an internal fence and the outside wall. Some of the craftsmen try to sell their carvings to the visitors. A woman visitor with bags of groceries sets up an umbrella and a large cooking pot over a fire in the courtyard and proceeds to make tamales.

\section{VISITS}

Tuesday is "conjugal day" for prisoners and their wives or girl friends. Only those who own or can borrow the use of a caraca have much opportunity for sexual intercourse. On Thursday and Sunday prisoners may receive as many visitors as they wish. Visitors may enter any time from 9:00 A.M. to 12:30 P.M., mingle freely with the prisoners, and leave any time from 12:30 P.M. to 3:00 P.M. The average number of visitors is roughly 50 on Tuesdays, 140 on Thursdays, and 250 on Sundays.

On visiting days in 1968 the prisoners had to stand behind a white line painted near the entrance, to keep order and to protect the visitors from excessive harassment by prisoners begging for coins. Visitors who did not come regularly or who appeared to be wealthy were assigned a prisoner as an escort to conduct them to the prisoner they wished to visit. The escort cleared the way through the other prisoners and loudly repeated a call of "Visitor to see [prisoner's name]." This service, which called for a tip, was later abolished; today runners bring the inmate to receive his visitors at the gate.

\section{Fighting}

Fights in the tanks occur frequently, mostly to retaliate for petty thievery, to avenge verbal insults, and to establish status through physical prowess. Although there are many close personal alliances in the prison, true homosexuality is not common and is not an important source of conflicts. In August 1970 there were only about six homosexuals in the prison. An American Negro pointed one of them out to me. "That's Maybelline. She lives with that young man over there, but she still flirts around with others she likes. She peroxides her hair and strolls the yard, smiling, winking, and weaving her hips. She's much more feminine than the real women they have in here."

A woman who regularly visits her husband in the prison was getting 
tired of going there because, as she said, "It seems that all they talk about is who they fought with and who slashed who." Chronic fighting and stealing are the most common causes of solitary confinement in las tombas ("the tombs"), a concrete block building with six small cells (about $5^{\prime}$ $\mathrm{x} 10^{\prime}$ ), each with a heavy door with a tiny slot for light and ventilation.

Fights in the caracas are rare. One occurred when a tiny terrier was attacked by a large mongrel, whereupon the owner of the former attacked his counterpart. Another happened over the use of the pay telephone.

\section{Status}

Status is a recurrent theme of the prisoners' conversations. In word play, Mexicans call Americans gibacho ("Frenchy") ; the Americans reciprocate with "greaser." A person's status on the outside has very little direct influence on his status in the prison, where wealth is the major determinant. In the prison, a destitute doctor has a low social position; a prosperous peasant is high on the totem pole.

Heroin addiction divides the prison society, placing about 250 persons in an outcaste group. It is more important than language, nationality, or personality as a determinant of one's associates: "clean" prisoners just do not get friendly with "hypes." Heroin addicts are despised not so much for their compulsive habit per se as for their tendency to be poor and completely untrustworthy.

Personality also influences social status. One well-dressed Mexican, who had served eleven years on a murder conviction, has the reputation of being "a mean one who takes money from the weaker prisoners." One American Negro is said to be "a real nice guy, a loner but not a hype."
At the top of the social scale are the wealthy, those with the best caracas, and the big drug dealers. Continually badgered for handouts by some prisoners and "donations" by the prison administration, a wealthy prisoner has considerable power to do what he wants; for example, he can effect arrangements to receive a woman prisoner into his caraca or a workshop in the evening.

Since the women are rather isolated, the most important events in their lives are these "dates" with the male prisoners and visiting days when they can go out into the general courtyard. The dates are anticipated with a great amount of preparation and attention to clothing, hairdo, and makeup and are discussed among the female prisoners in intimate detail. Payment per date is about $\$ 5$, of which the guards and matrons receive a small amount.

There often develops a fairly continuing relationship between a woman and her regular dates. One female prisoner said that when she arrived in 1965 the administration was very lenient about these liaisons and even allowed prostitutes from Tijuana to come to the prison; however, venereal disease became widespread and a serious morale problem developed out of the jealousies and possessiveness of some of the prisoners. This meant more fights and knifings. The warden resolved these problems, first, by excluding the outside prostitutes and, later, by conducting a mass "prison marriage" ceremony for couples and polyandrous groupings. Several of the persons involved were in fact legally married to others on the outside. Women were not allowed to live in the caracas; the ceremony was simply recognition of an agreement for exclusive sexual rights between a wom- 
an and one or more men while they were in the prison.

Women make most of their money in the prison economy by washing and ironing clothes for the male inmates. They enjoy taking care of the baby that one woman had and is raising in the prison. The young Mexican-American woman currently in the prison is happy, gregarious, attractive, and widely liked and seems to have made a satisfactory adjustment to prison life. Some years ago an American woman found it difficult to be in close quarters with lower-class Mexican women; she regarded them as "ignorant and filthy" and arranged to bring into a corner of the prison a small trailer, in which she lived for several years. When she completed her sentence, the prison authorities sold the trailer to an American male prisoner, who lived in it until a new warden had it removed.

This trailer, the new warden maintained, was the headquarters of a racket that imported stolen cars into Mexico. Even after its owner was moved to a caraca, he retained his position near the top of the social scale: he had money, a caraca with a refrigerator and a television set, and a servant. He was the center of a complex network of guard-prisoner reciprocities; he was asked by tank prisoners to store their valuables in his caraca for safekeeping; he was the center of a communications network. Eventually he acquired so much power that he became a threat to the prison administration. The guards raided his caraca, confiscated his cash -about $\$ 500$ - and his belongings, and transferred him to a tank. Gradually they sold his furnishings back to him; they even made an offer to sell him another caraca, but he turned it down, having in the meantime built a makeshift apartment in his tank.

\section{Conclusions}

This prison contrasts greatly with Canadian and American prisons, primarily because it is allowed to operate as a free enterprise market economy. Intimately involved in day-to-day economic decisions, the inmates are active participants in a society that is close to the social realities of life outside the prison.

In Canadian and American prisons, the economy is highly administered, with a standard issue of uniforms, living facilities, and food; manifestations of a market economy are largely suppressed because they are seen as undermining the administration's authority and discipline. Equality among the prisoners is regimented and enforced. Administrators design and carry out a program to inculcate passive obedience, which may be useful in the peaceful operation of a prison but is not particularly useful preparation for life outside the prison.

At La Mesa Penitenciaria, inmates receive income in the form of goods and money from visiting friends and relatives; by working in a workshop or food shop or as servants for other prisoners; by successful bartering; or by selling drugs. They must contribute to the maintenance of the prison, but a survival level of food and medical care is free. Beyond that, they must pay for their clothing, living quarters, and additional food.

Social status at La Mesa is correlated with wealth. A strong incentive to earn money comes from the internal prison economy rather than fear of punishment by the administration. Heroin addicts are despised not so 
much for their compulsive habit as for their tendency to be poor and untrustworthy.

The illegal payment of mordidas sanctions and perpetuates circumvention of the law. Instead of promoting a legal conscience and a genuine respect for the law among the prisoners, the system promotes a set of brutal situational ethics. New inmates who are poor or too sick to work may barely survive. Instead of treating drug addiction, the administration has allowed the prison to become an easy place to buy drugs.

It seems that Anglo-American and Mexican penal systems could learn from each other. We need some middle ground between the administered regimentation of American prisons and the inequalities of Mexican prisons. The open visiting policy of Mexican prisons is a positive feature that could be retained under an equitable administration. Anglo-American penologists could also allow a limited market economy to operate within a prison without undermining its orderly administration. Mexican penologists, finally, need to insist that some regimentation is humane and that disregard for the law within the prison promotes a general disregard for the law in the wider society. 